\title{
OPTIMIZING THE DRY PLANT SAMPLE PREPARATION METHOD FOR EFFICIENT DNA EXTRACTION IN SYRINGA VULGARIS
}

\author{
Mikhail Yu. Tretiakov ${ }^{1}$, Valeriy K. Tokhtar ${ }^{1}$, Anna E. Ivleva ${ }^{1}$, Julia N. Kurkina ${ }^{1}$, \\ Irina V. Batlutskaya ${ }^{1}$, Igor V. Lyashenko ${ }^{1}$ \\ ${ }^{1 *}$ Belgorod State National Research University, 85 Pobedy St., Belgorod, 308015, Russia; \\ *Corresponding Author Mikhail Yu. Tretyakov, email: tretyakovmiy@gmail.com;
}

Received November 2021; Accepted December 2021; Published January 2022;

DOI: https://doi.org/10.31407/ijees12.124

\begin{abstract}
The aim of the study was optimization of the method of DNA extraction from plant tissues. The cultivar 'Margaret Fenicia' of Syringa vulgaris $L$. species was selected as an object for DNA extraction from plant tissues. The choice of the object stems from the fact that young and old leaves and flowers were simultaneously sampled on the plant during the same growing season. Weighing was performed on a CAS CUV620HV scale with $620 \pm 0.001 \mathrm{~g}$ weighing limit. The greatest amount of DNA can be extracted from dry material of young leaves. Increasing the weight of the sample up to $30 \mathrm{mg}$ allows a significant increase in the amount of extracted DNA. In conclusion, the degree of DNA extraction from dried young leaves when increasing the sample weight to $30 \mathrm{mg}$ from the recommended $10 \mathrm{mg}$ with the same volume of extracting increases by $18.82 \%$, in dried flowers by $58.9 \%$ and in dried old leaves by $44.5 \%$. Both vegetative and generative parts of a plant can be used as dry plant material for DNA production. The correlation between sample weight and extractable DNA for old leaves is 0.86, while the correlation between sample weight and target product when the lysis buffer is added before homogenization is -0.71 . Thus, it can be confidently stated that the method of adding the lysis buffer before homogenization significantly reduces the yield of extracted DNA. This suggests that research on this aspect of the work was most likely not studied by the developers of the extraction kits.
\end{abstract}

Key words: DNA; Dry matter; Extraction; Gentics; Plant. 